\section{Extenzográf alkalmazása a lisztvizsgálatokban}

\author{
Boros Norbert - Borbélyné Varga Mária - \\ Győri Zoltán \\ Debreceni Egyetem Agrár- és Müszaki Tudományok Centruma, \\ Mezőgazdaságtudományi Kar, Élelmiszertudományi, \\ Minőségbiztosítási és Mikrobiológia Intézet, Debrecen \\ nboros@agr.unideb.hu
}

\section{ÖSSZEFOGLALÁS}

Az extenzográfot széles körben használják a minőségellenőrzésben és a kutató laboratóriumokban a búzalisztek minőségének vizsgálatára. A leggyakrabban használt jellemzők az $R_{m}$, a nyújtással szembeni legnagyobb ellenállás; $R_{5}$, az $5 \mathrm{~cm}$-re történö nyújtásnál fellépö ellenállás; $E$ a nyújthatóság (a görbe hossza); Rm/E a legnagyobb ellenállás és a nyújthatóság aránya; és A a görbe alatti terület nagysága. Az extenzográf jól alkalmazható a lisztek minösitésére és besorolására a belölük készült tészta fizikai tulajdonságai alapján. Másik fontos alkalmazási területe az extenzográfnak az extenzográfos jellemzők használata a búzanemesitésben. Ezenkivül az extenzográf kiváló eszköz a különbözö összetevőknek (oxidálószerek, enzimek, sók és adalékanyagok) a búzalisztek tésztatulajdonságaira kifejtett hatásának vizsgálatára, és a fagyasztva történö tárolás során bekövetkezö változások mérésére is. Jelen tanulmányunkban az extenzográf alkalmazásának lehetőségeivel foglalkozó szakirodalmat dolgoztukfel.

Kulcsszavak: extenzográf, reológiai tulajdonságok

\section{SUMMARY}

The extensograph is widely used in quality control and research laboratories studying wheat flour quality. The most commonly used measurements include $\mathrm{Rm}$, the maximum resistance (maximum height of the curve); $R 5$ the resistance at a constant extension of $5 \mathrm{~cm}$; E, extensibility (total curve length); $\mathrm{Rm} / \mathrm{E}$, the ratio of maximum resistance to extension; and $A$, the area under curve. The extensograph has proved useful in the classification and assessment of flours on the physical dough properties. Another important application is its use in wheat breeding programs. Furthermore, extensograph is an excellent tool to study the effects of a wide range of ingredients on dough properties of wheat flour like oxidants, enzymes, salt and additives), and it can also be used measure the changes during the frozen storage. In the present study we provide a review of the scientific literature concerning the possible applications of the extensograph.

Keywords: extensograph, rheological properties

A malom és sütőipar számára döntő jelentőségü az állandó minőségü liszt használata. A különböző sütőipari termékek különböző igényeket támasztanak a liszt minőségével és a tészta tulajdonságaival szemben.

Az állandó minőség iránti igény szükségessé tette olyan objektív vizsgálati módszerek kifejlesztését, amelyek információkat adnak a liszt minőségére vonatkozóan, és hűen tükrözik a sütési eljárás különböző fázisaiban a tészta viselkedését.

$\mathrm{Az}$ extenzográf alkalmas a tészta nyújtási tulajdonságainak mérésére, különösen a nyújtással szembeni ellenállás (rezisztencia) és a nyújthatóság megállapítására, ezáltal megbízható információkat szolgáltat a tészta sütési viselkedésére vonatkozóan.

Semelyik más müszerhez sem hasonlíthatóan, az extenzográf kimutatja a lisztben található adalékanyagok, úgymint aszkorbinsav, enzimek és emulgeáló szerek hatását, ezáltal lehetővé téve az egyes lisztek reológiai tulajdonságainak megállapítását és a felhasználási célnak megfelelő „reológiai optimumhoz” való igazítását. A „reológiai optimum" a tészta fizikai tulajdonságát jellemzi, ami az adott feldolgozási feltételek között az optimális sütési eredményt szolgáltatja.

Az extenzogram alapján a következő jellemzők határozhatók meg:

- nyújtással szembeni ellenállás

- nyújthatóság

- a görbe maximuma

- görbe alatti terület (energia)

- nyújthatóság/ellenállás aránya

- nyújthatóság/maximum

A búzalisztből készült tészták extenzogramjait négy liszt kategóriába lehet besorolni a tészta erőssége alapján: gyenge, közepes, erős, és nagyon erős. Altalánosságban azok, amelyeknél a görbe alatti terület $80 \mathrm{~cm}^{2}$-nél kisebb, a gyenge, amelyeknél 80-120 $\mathrm{cm}^{2}$, azok a közepes kategóriába, amelyek területe 120-200 $\mathrm{cm}^{2}$ közötti, nagyon erös kategóriába sorolhatók. A jó nyújtással szembeni ellenállás és a jó nyújthatóság a kívánatos tészta jellemzői.

Az extenzográfos vizsgálat részleteit különböző standardok tartalmazzák:

- AACC Standard No. 54-10

- ISO 5530-2

- ICC Standard No. 114/1

Két általánosan elfogadott módszer létezik, ezek az American Association of Cereal Chemists (AACC 1983, Method 54-10) és az International Association for Cereal Chemistry (ICC 1980, Standard No.114.) módszerek. Mindkét eljárás során 300 g lisztből, $6 \mathrm{~g}$ sóból és a szükséges vízből a tészta a farinográf nagy dagasztó csészéjében $30{ }^{\circ} \mathrm{C}$-on az 500BU konzisztencia eléréséig tésztát készítünk. Az ICC módszer szerint a tészta dagasztása pontosan 5 percig tart, ezzel szemben az AACC módszer alapján a tésztát 1 percig dagasztjuk, majd 5 percig pihentetjük, ezt követően pedig a kívánt 
konzisztencia eléréséig dagasztjuk. Ennek következtében az ICC módszernél a tészta munkája és az oxigén hatása közel állandó, azonban az AACC módszernél a tészta kialakulás optimális, de a bevitt munka és az oxidálódás különböző. Ezek a különbségek eltérő extenzográfos értékeket eredményezhetnek ugyanazon liszt vizsgálata során. A dagasztást követően a két módszer lényegében megegyezik egymással.

Ezeken a standard módszereken kívül van egy elfogadott gyors módszer is, mely a vizsgálati idő csökkentésével időt takarít meg, ezáltal a tészta pihentetési ideje a gyártás során rendelkezésre állóhoz válik hasonlóvá. Az így kapott eredmények szoros korrelációban állnak azokkal az eredményekkel, melyeket standard módszerekkel állapítottak meg.

\section{A TÉSZTÁK REOLÓGIAI TULAJDONSÁGAINAK VIZSGÁLATA}

A tészta reológiai tulajdonságai rendkívül fontosak mind a tészta megmunkálhatósága, mind pedig a végtermék minősége szempontjából. Számos módszer áll rendelkezésre a búzaliszt tészták reológiai tulajdonságainak vizsgálatára (Bloksma és Bushuk, 1988; Walker és Hazelton, 1996).

A búzalisztből készített tészta reológiai tulajdonságait a magyar szabvány szerint Brabender Farinográffal (Valofigráffal) vagy a francia kenyértípus jellemzésére kifejlesztett Alveográffal határozzuk meg. A Farinográf a legelterjedtebben használt tésztavizsgálati módszer, mely egyaránt jellemzi a tészta kialakulását, stabilitását és ellágyulását. Ezen tulajdonságok alapján a különböző búzaminták minőségi csoportokba sorolhatók (A1-től C2-ig). A farinográfos tulajdonságok alapján azonos csoportokba sorolt minták között a tapasztalatok szerint további tulajdonságbeli különbségek lehetnek. E megállapítás nem meglepő, hiszen a Farinográf nem jellemzi a tészta valamennyi tulajdonságát, így például nem jellemzi közvetlenül a tészta nyújthatóságát sem. A tészta nyújthatóságára a sikérterülés, a farinográfos ellágyulás és stabilitás adatok, valamint az alveográfos $\mathrm{P}$ és $\mathrm{L}$ értékek közvetetten utalnak ugyan, közvetlen mérésre azonban az Extenzográfot, illetve a Texture Analyser (Stable Micro Systems) készüléket használják világszerte (Rakszegi et al., 2005).

Az extenzográf a farinográfos vizsgálat kiegészítéseként információkat ad a tészta azon jellemzőire vonatkozóan, amiket a farinográf nem vet fel, ezek pedig a tészta nyújthatósága, a tészta nyújtással szembeni ellenállása (rezisztencia), és ezek aránya (Brabender, 1956, 1965; Brabender és Pagenstadt, 1957). Az $R_{50}$ paraméter a tészta kezelhetőségi tulajdonságára utal és a készítés alatti toleranciájára (Brabender, 1953).

1936-os bemutatása óta az extenzográfot széles körben használják minőségellenőrzésben és kutatólaboratóriumokban a búzalisztek vizsgálatára. $\mathrm{Az}$ extenzográfos mérést a búzalisztből készült tészták fizikai jellemzőinek meghatározásához használják. A leggyakrabban vizsgált paraméterek: $R_{m}$ a maximális ellenállás (a görbe maximális magassága) extenzográf egységben kifejezve, $R_{5}$ $5 \mathrm{~cm}$-re történő nyújtás esetén jelentkező ellenálló képesség (ellenállás) (néha különböző nyújtást alkalmaznak) extenzográf egységben kifejezve; $E$ nyújthatóság (a görbe hossza) centiméterben kifejezve; $R_{m} / E$ a maximális ellenállás és a nyújthatóság aránya; és $A$ a görbe alatti terület négyzetcentiméterben kifejezve.

Ezek a paraméterek, kivéve az állandó nyújtással szembeni ellenállás, már szerepeltek Mueller (1936), Munz és Brabender (1940a, b) korai extenzográfos tanulmányaiban. Dempster et al. (1952, 1953, 1955) elöször használták a tészták összehasonlítására az állandó nyújtással szembeni ellenállását állandó terhelés mellett.

A különböző sütőipari termékek készítéséhez eltérő extenzográfos értékekkel jellemezhető lisztekre van szükség. Hay (1993) a kelt tészta magassága és térfogata és a tészta reológiai tulajdonságai között szoros összefüggést talált, különösen az extenzográfos energia tekintetében. A vizsgálati eredményei kimutatták, hogy azonos lisztből készített kenyér sütőipari minőségéből nem lehet a kelt tészta minőségére következtetni.

Kekszgyártáshoz használt tészták reológiai tulajdonságainak vizsgálata során megállapították, hogy a tészta erőssége a kelesztési idő növekedésével párhuzamosan csökken. A tészta reológiai tulajdonságai a kelesztés első órájában változnak meg szignifikánsan (Doescher és Hoseney, 1985).

Indrani and Venkateswara Rao (2000) szerint a reológiai jellemzők, mint a farinográfos vízfelvevő képesség, extenzográfos arány és görbe alatti terület szoros korrelációban állnak a parotta tészta minőségi jellemzőivel, a tészta terülésével, az elszakításához és összenyomásához szükséges erő mértékével.

\section{A LISZT FEHÉRJE-ÖSSZETÉTELÉNEK HATÁSA AZ EXTENZOGRÁFOS JELLEMZÖKRE}

Gupta et al. (1991) 48 ausztráliai és 53, a világ más részeiből származó genotípusú búzafajtánál a kis és nagy molekulatömegü (LMW és HMW) glutenin alegységek jelenlétének a tészta minősére gyakorolt hatását vizsgálták. Megállapították, hogy a világban termesztett búzáknál a nagy molekulatömegü alegységek jóval szorosabb korrelációban állnak $(\mathrm{r}=0,75, \mathrm{P}<0,001)$ a tészta maximális ellenállásával $\left(R_{\max }\right)$, mint a kis molekulatömegü alegységekkel $(\mathrm{r}=0,56, \mathrm{P}<0,001)$. Az ausztrál búzafajtáknál viszont a kis molekulatömegủ glutenin alegységek szorosabb korrelációban állnak $(\mathrm{r}=0,72, \quad \mathrm{P}<0,001) \quad$ a tészta maximális ellenállásával $\left(R_{\max }\right)$, összehasonlítva a nagy molekulatömegű alegységekkel ( $\mathrm{r}=0,48$, $\mathrm{P}<0,01)$. A tészta nyújthatósága azonos szinten korrelál a kis $(\mathrm{r}=0,44, \quad \mathrm{P}<0,001)$ és a nagy molekulatömegü alegységekkel $(\mathrm{r}=0,43, \mathrm{P}<0,001)$ a világban, de Ausztráliában csak a kis molekulatömegü alegységeknél találtak szignifikáns korrelációt $(\mathrm{r}=0,54, \mathrm{P}<0,001)(1 ., 2$. táblázat $)$. 
Eltérő genotípusú búzák extenzográfos jellemzői

\begin{tabular}{lccc}
\hline Tulajdonság(1) & Mértékegység(2) & Szélső értékek(3) & Átlag(4) \\
\hline A világ búzafajtái(6) & & & \\
$\quad$ Legnagyobb nyújtással & & & \\
szembeni ellenállás(7) & BU & $120-770$ & 351 \\
Nyújthatóság(8) & $\mathrm{cm}$ & $16-26$ & 21,5 \\
Ausztrál búzafajták(9) & & & 2,2 \\
Legnagyobb nyújtással & $\mathrm{BU}$ & $190-392$ & 294 \\
szembeni ellenállás(7) & $\mathrm{cm}$ & $19,5-25$ & 22,4 \\
Nyújthatóság(8) & & & 46,4 \\
\hline
\end{tabular}

Forrás: Gupta et al. (1991)(10)

Table 1: Extensograph properties of different genotype wheat

Attribute(1), units(2), range(3), mean(4), standard deviation(5), world wheats(6), maximum resistance(7), extensibility(8), Australian wheats(9), source(10)

Eltérő genotípusú hazai búzafajták extenzográfos jellemzői 2006-ban

\begin{tabular}{lccc}
\hline Tulajdonság(1) & Mértékegység(2) & Szélső értékek(3) & Átlag(4) \\
\hline Legnagyobb nyújtással & & & \\
szembeni ellenállás(6) & $\mathrm{BU}$ & $40-524$ & 237 \\
Nyújthatóság(7) & $\mathrm{cm}$ & $9-21$ & 14,3 \\
Nyújtással szembeni & & & 114 \\
ellenállás(8) & $\mathrm{BU}$ & $40-422$ & 180 \\
Görbe alatti terület(9) & $\mathrm{cm}^{2}$ & $6-84$ & 45,6 \\
\hline
\end{tabular}

Forrás: Saját vizsgálati eredmények(10)

Table 2: Extensograph properties of different genotype wheat of Hungary in 2006

Attribute(1), units(2), range(3), mean(4), standard deviation(5), maximum resistance(6), extensibility(7), resistance at constant extension of $5 \mathrm{~cm}(8)$, area(9), source: own examination results(10)

Scanlon et al. (1990) szerint a tészta nyújthatósága a lisztek fehérje-összetétele alapján jobban becsülhetö, mint a gliadin tartalom alapján. Magas szignifikáns $(\mathrm{P}<0,001)$ korreláció található a liszt minősége (különös tekintettel a tészta nyújtással szembeni ellenállására) és a gliadin fehérjék, valamint a nagy molekulatömegü glutenin alegységek mennyisége között (Campbell et al., 1987, Cressey et al., 1987).

Gupta et al. (1992) megállapították, hogy a minőségi paraméterek kizárólag a glutenin mennyiségétől (a fehérjében található glutenin (PG), és a lisztben található glutenin FG) függ. A két jellemző közül is a lisztben található glutenin mennyisége áll szorosabb korrelációban az extenzográfos nyújthatósággal, a farinográfos tészta kialakulási idővel és a kenyér térfogatával.

Zhang et al. (2007) tavaszi búzával végzett vizsgálatuk eredményeként megállapították, hogy az 1B/1R transzlokációs vonalakban szignifikánsan nagyobb az $\omega$-gliadinok mennyisége, és kisebb a gluteninek és a kis molekulatömegü glutenin alegységek mennyisége, azonban nem találtak szignifikáns eltérést a tésztatulajdonságokban és a kenyérminőségben a transzlokációt nem tartalmazó vonalakhoz képest. A transzlokációt nem tartalmazó vonalak között mérsékelt és magas korrelációs koefficienseket találtak glutenin és frakciói, valamint a farinográfos tészta kialakulási idő (DT, r=0,85-0,92), a stabilitás (ST, r=0,81-0,93) és az extenzográfos maximális rezisztencia $\left(R_{\max }, \quad \mathrm{r}=0,90-0,93\right) \quad$ között. A gliadin:glutenin arányok szignifikáns és negatív összefüggést mutattak a tésztatulajdonságokkal és a kenyérminőséggel.

Az 1BL/1RS transzlokációval rendelkező búzák lisztje gyengébb minőségü, ami megmutatkozik az alacsonyabb fehérjetartalmukban is. Ezen tészták keverés során mért ellenállása kisebb, kisebb a nyújthatósága, nagyobb a nyújtással szembeni ellenállás és a nyújthatóság $(\mathrm{R} / \mathrm{E})$ aránya, és kisebb a cipó térfogata. A genetikai hatások és a termesztési környezet szignifikáns hatással volt valamennyi minőségi paraméterre (Fenn et al., 1994).

Zhang et al. (2007) szerint a genotípus hatások szignifikánsak a fehérje frakciók mennyiségére nézve, és alapvetően meghatározzák a liszttulajdonságokat és a kenyér minőségi paramétereit. A genotípusok közötti variáció mértéke sokkal magasabb, mint az egyes környezetek között az összes vizsgált paraméter tekintetében (3. táblázat). Az összes sikér mennyisége, gliadin:glutenin arány, farinográfos stabilitás (ST), extenzográfos max. rezisztencia $\left(R_{\max }\right)$ között $15,5-32,9 \times 10^{6} \quad \mathrm{AU} / \mathrm{mg}, \quad 2,5-2,7, \quad 2,2-25,1 \mathrm{~min}$, 92,9-593,9 BU a genotípusok között, míg ellenben a különböző termőhelyeknél ugyanezek az értékek: $18,6-22,7 \times 10^{6} \quad \mathrm{AU} / \mathrm{mg}, \quad 3,8-4,6, \quad 3,9-4,1 \mathrm{~min}$, 196,3-334,5 BU. 
A tésztatulajdonságok változása 33 genotípusnál négy környezetben

\begin{tabular}{|c|c|c|c|c|c|c|}
\hline \multirow{2}{*}{ Jellemző(1) } & & \multirow{2}{*}{ Átlag(2) } & \multirow{2}{*}{$\mathrm{SD}(3)$} & \multicolumn{2}{|c|}{ Szélső értékek(4) } & \multirow[b]{2}{*}{ Környezet(7) } \\
\hline & & & & Összes(5) & Genotípus(6) & \\
\hline \multirow{7}{*}{$\begin{array}{l}\text { Tészta- } \\
\text { tulajdonságok(8) }\end{array}$} & & & & & & \\
\hline & Liszt fehérjetartalma $(\%)(9)$ & 10,5 & 1,2 & $7,9-13,7$ & $9,3-12,5$ & $9,5-11,5$ \\
\hline & Szedimentációs érték (ml)(10) & 14,6 & 3,1 & $8,0-23,0$ & $10,6-21,4$ & $13,7-15,6$ \\
\hline & Kialakulási idő (min)(11) & 4,6 & 2,9 & $0,9-19,3$ & $2,1-12,8$ & $3,4-5,8$ \\
\hline & Stabilitás $(\min )(12)$ & 6,1 & 5,8 & $1,3-41,0$ & $2,2-25,1$ & $3,9-9,4$ \\
\hline & Nyújthatóság (mm)(13) & 179,7 & 24,3 & $131,6-256,0$ & $148,2-239,1$ & $172,7-188,9$ \\
\hline & $\begin{array}{l}\text { Legnagyobb nyújtással szembeni } \\
\text { ellenállás }(B U)(14)\end{array}$ & 267,1 & 137,2 & $72,4-772,0$ & $92,9-593,9$ & $196,3-334,5$ \\
\hline
\end{tabular}

Forrás: Zhang et al. (2007)(15)

Table 3: Variation of the dough properties among 33 genotypes in four environments

Parameter(1), mean(2), standard deviation(3), range(4), overall(5), genotype(6), environment(7), dough properties(8), flour protein content(9), sedimentation volume(10), development time(11), stability(12), extensibility(13), maximum resistance(14), source(15)

\section{KÜLÖNBÖZÖ ALAPANYAGOK HATÁSA A BÚZALISZTEK TULAJDONSAGGAIRA}

$\mathrm{Az}$ extenzográfot széles körben használják a különböző alapanyagok búzalisztek reológiai tulajdonságaira kifejtett hatásának vizsgálatára.

D’Appolonia (1984) megvizsgálta a különféle anyagoknak - mint a só, cukor, növényi zsírok, élesztő és zsírmentes tejpor - a búzalisztek farinográfos jellemzőire gyakorolt hatását. Galal et al. (1978) vizsgálatai során kimutatta, hogy a hozzáadott só csökkenti a vízfelvételt, növeli a tészta kialakuláshoz szükséges időt és a tészta stabilitását. Fisher et al. (1949) és Evans et al. (1974) kimutatták, hogy a nátrium-klorid szint növelésével növekszik a nyújtással szembeni rezisztencia, a nyújthatóság és a görbe alatti terület nagysága. Preston (1989) szerint a nátriumion sói kis mennyiségben $(0,05-0,10 \mathrm{M})$ javítják a tészta erősségét, nagyobb koncentrációban (0,5-1,0 M) csökkentették azt, és növelték a farinográfos vízfelvételt.

Indrani és Venkateswara Rao (2007) megállapították, hogy tojás hozzáadására az extenzográfos arány és a görbe alatti terület megnőtt $\left(3,35-3,45 ; 125-14,5 \mathrm{~cm}^{2}\right)$. Amikor olajt adtak a tésztához, az extenzográfos és mixográfos jellemzők romlása volt megfigyelhető, jelezve a tészta erősségének szignifikáns csökkenését.

A sütőipari termékek jelentős forrásai a tápanyagoknak, úgymint az energia, fehérje, vas, kalcium és számos vitamin. A hagyományos kenyér és a különféle kekszek 7-8\% fehérjét tartalmaznak, ami nagyon alacsony. A legtöbb sütőipari termék könnyen dúsítható és erősíthető olcsó fehérjékkel, különféle vitaminokkal és ásványianyagokkal a célcsoportok és a lakosság érzékeny részének speciális igényeihez igazodva (Indrani et al., 2007).

Egyre nagyobb az érdeklődés a búzalisztek magas lizin tartalmú anyagokkal történő dúsítása iránt, olyanok, mint a szója, vagy a feketeszemü bab, ami képes javítani a sütőipari termékek esszenciális aminosav tartalmát. Hallén et al. (2003) szerint a szójaliszt növeli a búzából készült kenyér táplálkozási értékét, javítja a fehérje minőségét, mert lizint tartalmaz, amiből a búzában kevés található. Maforimbo et al. (2004) megállapították, hogy a fizikailag kezelt (hántolt és 3 percig gőzölt) szójalisztet (PMSF, physically modified soy flour) tartalmazó tészta nagyobb ellenállást mutatott a nyújtással szemben $\left(R_{m}\right)$, nagyobb toleranciát, jobb keverési stabilitást, nagyobb vízfelvevő és vízmegkötó képességet, mint a nyers szójalisztet tartalmazó szójából és búzából készültt tészta.

Yousseff és Bushuk (1986) a lóbabból készült lisztet és fehérje készítményt kevertek a búzaliszthez. A farinográfos és extenzográfos vizsgálatok alapján megállapították, hogy a búzaliszthez kevert nem búza összetevők szignifikánsan megváltoztatták a tészta reológiai tulajdonságait.

Doxastakis et al. (2005) spagetti készítése során a búzadarát különböző mennyiségü csillagfürt fehérjével helyettesítették a fehérjetartalom növelése érdekében. A hozzáadott csillagfürt fehérjék hatására csökkent a tészta kialakulási idő és a maximum konzisztencia érték, ez a gyengítő hatás feltételezhetően a búzadara sikérvázának és a csillagfürt fehérjék között fellépő kölcsönhatásnak tulajdonítható. A tolerancia index viszonylag kicsi volt az összes mintánál, jelezve, hogy a búzadara minták sikérje kellően rugalmas és nyújtható volt. Az extenzográffal végzett mérések azt mutatták, hogy a LPI-E százalék 0-20\%-ra történő növelésével kevésbé nyújthatóvá válik a tészta, amit a magasabb $R_{50} / E_{x}$ arány is jelzett. Ezzel szemben, ha a csillagfürt fehérje tartalmat 5\%-ra emelték, a görbe alatti terület (a tészta elszakadásához szükséges energia) jelentősen megnőtt, viszont ezen csillagfürt fehérje tartalom fölött a görbe alatti terület csökkenése volt tapasztalható, de még mindig a kizárólag búzadarából készült tészta értéke fölötti volt. Azonban, ha az LPI-E mennyiségét 50\%-ig növelték, a tészta nagyon gyenge lett, csökkent a kialakulási ideje, a stabilitása, valamint gyengült a nyújthatósága és a nyújtással szembeni ellenállása.

A paradicsom mag liszt hatására javult a vízfelvevő képesség, nőtt a tészta kialakulási idő, a tészta stabilitása, és ezzel ellentétben csökkent a 
tészta nyújthatósága, a nyújtással szembeni ellenállása és a tészta energiája. A paradicsommag liszt javította a gázképződést, a nedvességtartalmat és a kenyér keresztmetszetét (Yaseen et al., 1991).

$\mathrm{Az}$ almapép az almalé gyártás mellékterméke, gazdag forrása a rostoknak és polifenoloknak (emészthető rost tartalma 51,1\%). Az almapép antioxidáns tartalma miatt fontos szerepet játszhat a betegségek megelőzésében. Az almapépet keverték be búzalisztbe $5 \%, 10 \%, 15 \%$-os arányban és vizsgálták a tészta reológiai tulajdonságait. A vízfelvétel szignifikánsan növekedett 60,1\%-ról 70,6\%-ra, ha az almapép tartalmat 0-ról 15\%-ra növelték. A tészta stabilitása csökkent és a tolerancia index nőtt, jelezve a tészta ellágyulását. A nyújtással szembeni ellenállás szignifikánsan megnőtt 336-ról 742 BU-ra, ezzel szemben a tészta nyújthatósága 127-ről 51 mm-re csökkent (Sudha et al., 2006).

Indrani et al. (2007) a WPC (whey protein concentrate), mint funkcionális alapanyag használatának lehetőségeit vizsgálták az indiai tradicionális termékben. A búzaliszt 5, 10 és $15 \%$-át tejsavó fehérjével helyettesítették, és megvizsgálták az így készült tészták farinográfos, extenzográfos, amilográfos jellemzőinek változását, valamint a kész parotta minőségére és mikroszerkezetére gyakorolt hatását.

A farinográfos adatok azt mutatták, hogy ha a búzalisztet WPC-vel helyettesítették, csökkent a farinográfos vízfelvétel. A tészta stabilitásának növekedése $10 \%$-os szint felett volt tapasztalható. Abban az esetben, ha a savófehérjét 10\%-tól magasabb arányban használták, csökkent a tészta stabilitása. Az extenzográfos nyújtással szembeni ellenállás és a görbe alatti terület növekedett a tejsavó arányának 10\%-ig történő növelésével, azonban a nyújthatósági értékek csökkenése volt megfigyelhető, ha a tejsavó szintet $15 \%$-ra növelték (4. táblázat). Ez valószínüleg a gluténtartalom gyengülésének tulajdonítható, valamint a savófehérjék és a búza fehérje frakciók közötti kölcsönhatásnak, ami rideg tésztát eredményez.

A tejsavófehérjék hatása a búzalisztek extenzográfos jellemzőire

\begin{tabular}{ccccc}
\hline $\begin{array}{c}\text { WPC } \\
(\%)(1)\end{array}$ & $\mathrm{R}(\mathrm{BU})(2)$ & $\begin{array}{c}\mathrm{E} \\
(\mathrm{mm})(3)\end{array}$ & $\mathrm{R} / \mathrm{E}(4)$ & $\begin{array}{c}\text { Görbe alatti } \\
\text { terület }\left(\mathrm{cm}^{2}\right)(5)\end{array}$ \\
\hline 0 & 520 & 118 & 4,4 & 83 \\
5 & 756 & 116 & 6,5 & 105 \\
10 & 809 & 112 & 7,3 & 108 \\
15 & 555 & 78 & 7,1 & 50 \\
\hline WPC: & tejsavófehérje-tartalom(1), & $\mathrm{R}:$ & nyújtással & szembeni \\
ellenállás(2), E: nyújthatóság(3), & $\mathrm{R} / \mathrm{E}:$ & nyújtással & szembeni \\
ellenállás és a nyújthatóság aránya(4) & & & \\
Forrás: Indrani et al. (2007)(6)
\end{tabular}

Table 4: Effect of WPC on the extensograph characteristics of wheat flour

Whey protein contents(1), resistance to extension(2), extensibility(3), resistance/extensibility(4), area under curve(5), source(6)
Zadow (1981) vizsgálatai során hasonló eredményeket kapott, megállapította, hogy amikor kenyérkészítés során savófehérjét adtak a liszthez, az eredményül kapott tészta gyengébb és kevésbé nyújtható lett.

\section{ADALÉKANYAGOK HATÁSÁNAK VIZSGÁLATA EXTENZOGRAFFAL}

Napjainkban az adalékanyagok használata a sütöiparban mindennapos gyakorlat. Ezek használatának célja, hogy javuljon a tészta feldolgozási tulajdonsága, javuljon a friss kenyér minősége és a kenyér hosszabb ideig legyen eltartható. E célok érdekében különböző adalékanyagokat használnak, az utóbbi időben pedig enzimeket, amiknek köszönhetően a vásárlók körében keresett, adalékanyagoktól mentes termékeket állítanak elő (Rosell et al., 2000).

Di Cagno et al. (2002) a tejsavtermelö baktériumok és az exogén enzimek (glükóz-oxidáz, lipáz, endo-xylanáz, proteáz) közötti kölcsönhatást vizsgálták. Megállapították, hogy az enzimek hatására a tejsavképződés fokozódott és felgyorsult. $\mathrm{Az}$ Lb. Hilgardii 51B baktériumtörzzsel kezelt tésztákhoz adott enzimek a tészta nyújtási ellenállásában $(\mathrm{R})$ jelentős változásokat okoztak (5. táblázat).

5. táblázat

Lb. hilgardii baktériumokkal és/vagy különböző enzimekkel készített tészták extenzográfos jellemzői

\begin{tabular}{lcc}
\hline Minták(1) & $\mathrm{R}(2)(\mathrm{EU})$ & $\mathrm{E}(3)(\mathrm{mm})$ \\
\hline Lb. hilgardii 51B & 700 & 83 \\
Glükóz-oxidáz(4) & 410 & 127 \\
Lb. hilgardii 51B + glükóz-oxidáz & 660 & 84 \\
Lipáz(5) & 910 & 81 \\
Lb. hilgardii 51B + lipáz & 820 & 83 \\
$\alpha$-Amiláz(6) & 810 & 82 \\
Lb. hilgardii 51B + $\alpha$-amiláz & 760 & 90 \\
Proteáz(7) & 190 & 186 \\
Lb. hilgardii 51B + proteáz & 450 & 130 \\
\hline
\end{tabular}

R: nyújtással szembeni ellenállás(2), E: nyújthatóság(3)

Forrás: Di Cagno et al. (2003)(8)

Table 5: Brabender extensograph parameters of doughs started with Lb. Hilgardii $51 B$ and/or several microbial enzymes Samples(1), resistance to extension(2), extensibility(3), glucose oxidase(4), lipase(5), $\alpha$-amilase(6), protease(7), source(8)

Míg a lipáz és $\alpha$-amiláz növelte az R-értéket 910 és 810 EU-ra, addig a glükóz-oxidáz és a proteáz ezt az értéket 410 és 190 EU-ra csökkentette. Ezzel szemben a glükóz-oxidáz és a proteáz enzimek $83 \mathrm{~mm}$-ről 127 és $186 \mathrm{~mm}$-re növelték a tészta nyújthatóságát $(\mathrm{E})$. Ezek az ellentétes változások tükröződnek az $\mathrm{R} / \mathrm{E}$ arányban, amely az Lb. Hilgardii 51B baktériumokat tartalmazó tésztához $(8,4)$ képest a lipázt és $\alpha$-amilázt tartalmazó tésztáknál az R/E arány magasabb (11,1 és 9,7), a glükóz-oxidáz és a proteáz enzimek tésztáinál ez az érték $(3,2$ és 1,0$)$ alacsonyabb volt. A tejsavtermelő 
baktériumok és enzimek együttes használatával a R/E arányok a középértékekhez közelítettek. A glükózoxidáz enzim és a Lb. Hilgardii 51B törzs együttes hatására megnőtt a tészta ellenállása $(\mathrm{R}=660 \mathrm{EU})$ és csökkent a nyújthatósága $(\mathrm{E}=84 \mathrm{~mm})$, ami a 7,8 R/E arányhoz vezetett. Azonos hatása volt proteáz enzimnek és a Lb. Hilgardii 51B törzsnek is, hatásukra a tészta nyújtással szembeni ellenállása $(\mathrm{R}=450 \mathrm{EU})$ megnőtt.

Rosell et al. (2000) különböző hidrokolloidok (nátrium-alginát, $\kappa$-karragenán, xantán-gumi és hidroxipropil metilcellulóz) hatását vizsgálták a tészta reológiai tulajdonságaira és a kenyér minőségére. Megállapították, hogy a hidrokolloidok növelik a tészta nyújthatóságát. Azonban a nyújthatóságot gyakorlatilag nem befolyásolta a pihentetési idő növelése.

El-Hady et al. (1996) megállapították, hogy az aszkorbinsav önmagában, vagy kálium-bromáttal, vagy nátrium-sztearoil-2-laktiláttal együttesen alkalmazva javította a végtermék minőségét. A liszthez kevert adalékanyagok hatására nőtt a tészta gázképző képessége, ezáltal javult a kenyérbél szerkezete, és nagyobb lett a tészta magassága. Az oxidálószerek hatására nőtt a fagyasztott tészta nyújtással szembeni ellenállása, és csökkent a nyújthatósága.

Maforimbo et al. (2004) hasonló eredményeket kaptak, vizsgálatuk során az L-aszkorbinsav 250 ppm-ről 500 ppm-re történő növelésével a nyújtással szembeni ellenállás növekedett $(\mathrm{P}<0,05)$ mind a nyers szójalisztből és fizikailag módosított szójalisztből készült tészta esetében is. L-aszkorbinsav csökkentette a szója-búza tészta nyújthatóságát 135 min pihentetés után $(\mathrm{P}<0,05)$.

\section{FAGYASZTOTT TÉSZTÁK VIZSGALATA EXTENZOGRAFFAL}

A fagyasztott tészták nagyon fontos része a sütési technológiának. A fagyasztott tésztából sütött kenyér minősége a fagyasztva tárolás során fokozatosan romlik (Inoue és Bushuk, 1991, 1992; Inoue et al., 1994, 1995; El-Hady et al., 1996). Két tényezőt határoztak meg, mint a sütési minőség csökkenésének lehetséges okaki: az első a gázképződés csökkenése, amit az élesztők aktivitásának csökkenése okoz, a második a tészta erősségének fokozatos csökkenése.

Inoue és Bushuk (1991) a kelesztett és keletlen tészták extenzográfos vizsgálata alapján megállapították, hogy a kelesztett tészták sikér szerkezete a fagyasztás során nagyobb mértékben sérülhet, mint a keletlen tésztáknál. Véleményük szerint a lisztek fehérje tartalmánál fontosabb a fehérjék minősége (Inoue és Bushuk, 1992).

Inoue et al. (1995) megállapították, hogy a kiolvasztott tészta nyújtással szembeni ellenállása $\left(R_{\max }\right)$ és a gáztermelő képessége szignifikánsan csökkent az első napon, a három felengedésvisszafagyasztást és a 70. napot követően, ezzel szemben a tészta nyújthatósága csak a tárolás 70. napja után nőtt szignifikánsan (6. táblázat).

A nem fagyasztott és a kiolvasztott tészták extenzográfos jellemzőinek és a gáztermelő képességének alakulása

\begin{tabular}{|c|c|c|c|c|}
\hline \multirow{3}{*}{$\begin{array}{l}\text { Fagyasztva tárolás } \\
\text { időtartama(2) }\end{array}$} & \multicolumn{4}{|c|}{ Tulajdonságok(1) } \\
\hline & \multirow{2}{*}{$\begin{array}{c}\text { Legnagyobb nyújtással } \\
\text { szembeni ellenállás (BU)(3) }\end{array}$} & \multirow{2}{*}{ Nyújthatóság (mm)(4) } & \multicolumn{2}{|c|}{ Gáztermelő képesség(5) } \\
\hline & & & $(\mathrm{mm} \mathrm{Hg})$ & $(\%)$ \\
\hline 0 nap (kontrol)(6) & 627 & 121 & 459 & 100 \\
\hline $1 \operatorname{nap}(7)$ & 530 & 122 & 447 & 97 \\
\hline $7 \operatorname{nap}(8)$ & 523 & 123 & 451 & 98 \\
\hline $\begin{array}{l}7 \text { nap, háromszori felenge } \\
\text { visszafagyasztás }(9)\end{array}$ & 407 & 121 & 378 & 82 \\
\hline $70 \operatorname{nap}(10)$ & 360 & 136 & 254 & 55 \\
\hline
\end{tabular}

Forrás: Inoue et al. (1994)(11)

Table 6: Extensograph properties and gassing power of nonfrozen and thwed frozen doughs

Properties(1), frozen storage time(2), maximum resistance(3), extensibility(4), gassing power(5), 0 days (control)(6), 1 day(7), 7 days(8), 7 days and three thaw-freeze cycles(9), 70 days(10), source(11)

\section{IRODALOM}

Bloksma, A. H.-Bushuk, W. (1988): Rheology and chemistry of dough (3rd ed. In Y. Pomeranz (Ed.). Wheat chemistry and technology (vol. II, pp. 131-217). St. Paul, Minnesota, USA: American Association of Cereal Chemists.

Brabender, C. W. (1956): The physical evaluation of flour performance. Bakers Digest, 30, 37.

Brabender, C. W. (1965): Physical dough testing. Cereal Science Today, 10, 291.

Brabender, C. W.-Pagenstadt, B. (1957): Flour testing and dough technology. Biscuit Maker and Plant Baker, January, 24.
Brabender, O. H. G. (1953): Extensograph, instruction manual, Duisburg: Brabender OHG No. 1702 E.

Campbell, W. P.-Wrigley, C. W.-Cressey, P. J.-Slack, C. R. (1987): Statistical correlations between quality attributes and grain-protein composition for 71 hexaploid wheats used as breeding parents. Cereal Chemistry, 64. 293-299.

Cressey, P. J.-Campbell, W. P.-Wrigley, C. W.-Griffin, W. B. (1987): Statistical correlations between quality attributes and grain-protein composition for 60 advanced lines of crossbred wheat. Cereal Chemistry, 64. 299-301. 
D'Apollonia, B. L. (1984): Types of farinograph curves and factors affecting them. In B. L. D'Apollonia, and W. H. Kunerth (Eds.). The farinograph hand book (18-23). St. Paul, Minnesota, USA: American Association of Cereal Chemists.

Dempster, C. J.-Hlynka, I.-Winkler, C. A. (1952): Quantitative extensograph studies of relacation of internal stresses in nonfermenting bromated and unbromated doughs. Cereal Chemistry, 29. 39.

Dempster, C. J.-Hlynka, I.-Anderson, J. A. (1953): Extensograph studies of structural relaxation in bromated and unbromated doughs mixed in nitrogen. Cereal Chemistry, 30. 492.

Dempster, C. J.-Hlynka, I.-Anderson, J. A. (1955): Influence of temperature onstructural relaxation inbromated and unbromated doughs mixed in nitrogen. Cereal Chemistry, 32. 241.

Di Cagno, R.-De Angelis, M.-Corsetti, A.-Lavermicocca, P.Arnault, P.-Tossut, P.-Gallo, G.-Gobbetti, M. (2002): Interactions between sourdough lactic acid bacteria and exogenous enzymes: effects on the microbial kinetics of acidification and dough textural properties. Food Microbiology, 20. 67-75.

Doescher, L. C.-Hoseney, R. C. (1985): Saltine crackers: changes in cracker sponge rheology and modification of a crackerbaking procedure. Cereral Chemistry, 62. 158-162.

Doxastakis, G.-Papageorgiou, M.-Mandalou, D.-Irakli, M.Papalamprou, E.-D'Agostina, A.-Resta, D.-Boschin, G.Arnoldi, A. (2005): Technological properties and nonenzymatic browning of white lupin protein enriched spaghetti. Food Chemistry, 101. 57-64.

El-Hady, E. A.-El-Samahy, S. L.-Seibel, W.-Brümmler, J. M. (1996): Changes in gas production and retention in non-prefermented frozen wheat doughs. Cereal Chemistry, 73. 472-477.

Evans, G. C.-Deman, J. M.-Rasper, V. F.-Voisey, P. W. (1974): An improved dough extensigraph. Journal of Canadian Institute of Food Science and Technology, 7. 263-268.

Fenn, D.-Lukow, O. M.-Bushuk, W.-Depauw, R. M. (1994): Milling and baking quality of 1BL/1RS translocation wheats. I. Effects of genotype and environment, 71. 189-195.

Fisher, M. H.-Aitken, T. R.-Anderson, J. A. (1949): Effects of mixing salt and consistency on extensograms. Cereal Chemistry, 26. 81-97.

Galal, A. M.-Varriano-Marston, E.-Johnson, J. A. (1978): Rheological dough properties as affected by organic acids and salts. Cereal Chemistry, 55. 683-691.

Gupta, R. B.-Bekes, F.-Wrigley, C. V. (1991): Prediction of physical from glutenin subunit composition in bread wheats: correlation studies. Cereal Chemistry, 68. 328-333.

Gupta, R. B.-Batey, I. L.-MacRitchie, F. (1992): Relationships between protein composition and functional properties of wheat flours. Cereal Chemistry, 69. 125-131.

Hallén, E.-Ibanoglu, S.-Ainsworth, P. (2003): Effect of fermented/germinated cowpea flour addition on the rheological and baking properties of wheat flour. Journal of Food Engineerin, 63. 177-184.

Hay, R. L. (1993): Effect of flour quality characteristics on puff pastry baking performance. Cereal Chemistry, 70. 392-396.

Indrani, D.-Prabhasankar，P.-Rajiv，J.-Venkateswara Rao，G. (2007): Influence of whey protein concentrate on the rheological characteristics of dough, microstructure and quality of unleavened flat bread (parotta). Food Research International in press

Indrani, D.-Venkateswara Rao, G. (2000): Effects of chemical composition of wheat flour and functional properties of dough on the quality of south Indian parotta. Food Research International, 33. 875-881.
Indrani, D.-Venkateswara Rao, G. (2007): Rheological characteristics ofwheat flour dough as influenced by ingredients of parotta. Journal of Food Engineering, 79. 100-105.

Inoue, Y.-Bushuk, W. (1991): Studies on frozen doughs. I. Effects of frozen storage and freeze-thaw cycles on baking and rheological properties. Cereal Chemistry, 68. 627-631.

Inoue, Y.-Bushuk, W. (1992): Studies on frozen doughs. II. Flour quality requirements for bread production from frozen dough. Cereal Chemistry, 69. 423-428.

Inoue, Y.-Sapirstein, H. D.-Takayanagi, S.-Bushuk, W. (1994): Studies on frozen doughs. III. Some factors involved in dough weakening during frozen storage and thaw-freeze cycles. Cereal Chemistry, 71. 118-121.

Inoue, Y.-Sapirstein, H. D.-Bushuk, W. (1995): Studies on frozen doughs. IV. Effects of shortening systems on baking and rheological properties. Cereal Chemistry, 68. 627-631.

Maforimbo, E.-Nsuyen, M.-Skurray, G. R. (2004): The effect $\mathrm{L}^{-}$ ascorbic acid on the rheological properties of soy-wheat dough: a comparison of raw and physically modified soy flours. Journal of Food Engineering, 72. 339-345.

Mueller, H. G. (1936): Die Mullerei, 12, 41.

Munz, E.-Brabender, C. W. (1940a): Prediction of baking value from measurements of plasticity and extensibility of dough. I. Influence of mixing and molding treatments upon physical dough properties of typical American wheat varieties. Cereal Chemistry, 17, 78 .

Munz, E.-Brabender, C. W. (1940b): Extensograms as a basis of predicting baking quality and reaction to oxidizing agents. Cereal Chemistry, 17, 313.

Preston, K. R. (1989): Effects of neutral salts of the lyetropic series ont he physical dough properties of canadian red spring wheat flour. Cereal Chemistry, 66. 144-148.

Rakszegi M.-Láng L.-Bedő Z. (2005): Tészta nyújthatóság vizsgálatok a búzanemesítésben. Martonvásár 2005/1, 12-13.

Rosell, C. M.-Rojas, J. A.-Benedito de Barber, C. (2000): Influence of hydrocolloids on dough rheology and bread quality. Food Hydrocolloids, 15. 75-81.

Scanlon, M. G.-NG. P. K. W.-Lawless, D. E.-Bushuk, W. (1990): Suitability of reversed-phase high-performance liquid chromatographic separation of wheat proteins for long-term statistical assessment of breadmaking quality. Cereal Chemistry, 67. 395-399.

Sudha, M. L.-Baskaran, V.-Leelavathi, K. (2006): Apple pomace as a source of dietary fiber and polyphenols and its effect on the rheological characteristics and cake making. Food Chemistry, 104. 686-692.

Walker, C. E.-Hazelton, J. L. (1996): Dough Rheological Tests (Back to the basics). Cereal Foods World, 41. 23-28.

Yassen, A. A. E.-Mohamed, H.-Shams El-Din, A.-Ramy Abd ElLatif, A. (1991): Fortification of balady bread with tomato seed meal. Cereal Chemistry, 68. 159-161.

Youssef, M. M.-Bushuk, W. (1986): Breadmaking properties of composite flours of wheat and faba bean protein preparations. Cereal Chemistry, 63. 357-361.

Zadow, J. G. (1981): Measurement of the effect of whey protein concentrates on fermenting doughs by the Instron Tester. Australian Journal of Dairy Technology, 36. 56-59.

Zhang, P.-He, Z.-Chen, D.-Zhang, Y.-Larroque, O. R.-Xia, X. (2007): Contribution of common wheat protein fractions to dough properties and quality of northern-style Chinese steamed bread. Journal of Cereal Science, 46. 1-10. 